\title{
Montagem, realismo e antropofagia: Eisenstein e Bazin em Canibal Holocausto (1980)
}

Felipe M. Guerra

\section{Resumo:}

Este artigo analisa o filme italiano Canibal Holocausto (Cannibal Holocaust), dirigido por Ruggero Deodato em 1980, comparando a linguagem utilizada pela obra com as teorias cinematográficas do russo Sergei Eisenstein e do francês André Bazin. Em períodos e em países diferentes, os dois teóricos discorreram, entre outros aspectos, sobre a montagem cinematográfica. Suas posições são opostas: enquanto nos ensaios de Bazin o que interessava eram as formas de reprodução da realidade, como o plano-sequência, Eisenstein via o filme como um discurso articulado construído a partir da edição das imagens. Assim, um defendia planos longos e profundidade de campo; outro, a criação através da montagem. O objetivo do presente trabalho é demonstrar que características das teorias de Bazin e de Eisenstein, mesmo opostas, podem ser observadas no filme de Deodato, por causa da sua mistura, original à época, de ficção com "falso documentário".

\section{Palavras Chave:}

Canibal Holocausto; análise fílmica; teorias da montagem; Sergei Eisenstein; André Bazin

\section{Abstract:}

This paper analyses the Italian movie Cannibal Holocaust, directed by Ruggero Deodato in 1980, comparing its language to the cinematographic theories by Sergei Eisenstein and Andre Bazin. In different times and countries, both theorists discourse, among other aspects, about the cinematographic montage. Their positions are opposite: while Bazin is interested in the forms of reproduction of reality, as the sequence plan, Eisenstein considered the movie as an articulated discourse constructed from the image edition. Thus, one defended long sequence plans and depth of field; the other, the creation through montage. The objective of this work is to demonstrate that some characteristics from the theories by Bazin and Eisenstein, even opposite, could be observed in the movie, because of its mixture of fiction and "false documentary", original at the time.

\section{Keywords:}

Cannibal Holocaust; film analysis; montage theories; Sergei Eisenstein; Andre Bazin 
Uma enorme tartaruga é retirada das águas do rio por dois homens. Em seguida, o primeiro golpe de facão é no pescoço; a lâmina decepa a cabeça do animal sem dificuldades, enquanto suas quatro patas se movem num reflexo involuntário. A mutilação continua: um dos homens abre o casco do animal a machadadas, seus órgãos internos são retirados, as patas são decepadas com o facão.

Esse registro gráfico do preparo de uma tartaruga como alimento é uma das cenas escabrosas de Canibal Holocausto, um polêmico filme dirigido pelo italiano Ruggero Deodato em 1980. Os que nada sabem sobre a produção podem achar a cena real demais. E ela é real!

A tartaruga morta é uma tartaruga de verdade, feita em pedaços diante da câmera. Outros animais reais também são mortos ao longo da narrativa, chegando a um ponto que, quando os atores começam a ser mortos de forma encenada, o espectador não confia mais em seus olhos, e, chocado com a violência verídica testemunhada até então, pode até acreditar que aquelas pessoas também estão sendo assassinadas.

Tal nível de "realismo" faz parte da proposta do diretor Deodato de criticar a violência e o sensacionalismo da mídia. Ele filmou Canibal Holocausto em forma de mockumentary (1), tentando convencer o espectador de que tudo o que ele vê é verdadeiro, sejam as mortes (reais) de animais ou as mortes (encenadas) de seres humanos.

Ironicamente, o cineasta caiu numa armadilha paradoxal: seu filme é tão violento e sensacionalista quanto a mídia que ele busca "criticar".
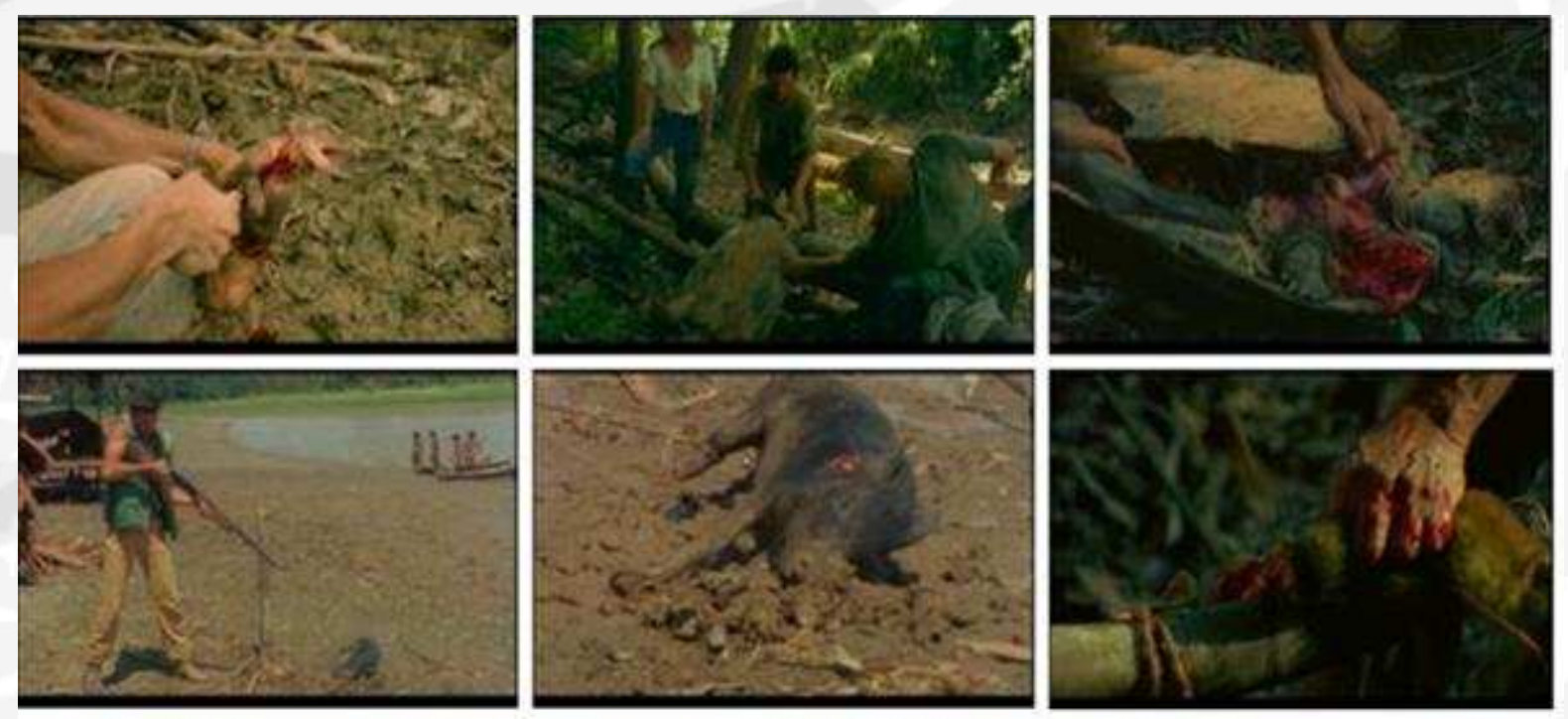

Animais foram realmente mortos em "Canibal Holocausto", mas pessoas não.

Canibal Holocausto desenvolve-se em duas linhas narrativas. A primeira é uma encenação visível: um antropólogo norte-americano chamado Harold Monroe (interpretado por Robert Kerman) lidera uma expedição à Amazônia em busca de quatro jovens cineastas nova-iorquinos que desapareceram enquanto faziam um documentário sobre as tribos canibais sul-americanas.

Nesta primeira parte, filmada em 35 milímetros, Monroe acaba testemunhando vários rituais violentos dos "primitivos" indígenas, até descobrir que os quatro desaparecidos foram mortos por uma das tribos.

Ele volta aos Estados Unidos levando as latas contendo os rolos de filme dos falecidos documentaristas. 
Até então, os jovens parecem ser vítimas dos terríveis canibais. Mas no momento em que os negativos são revelados e projetados, o foco do filme muda.

É quando começa a segunda parte de Canibal Holocausto. As cenas registradas pelos falecidos Alan Yates (interpretado por Gabriel Yorke), Faye Daniels (Francesca Ciardi), Mark Tomaso (Luca Barbareschi) e Jack Anders (Perry Pirkanen), em 16 milímetros, invadem a narrativa "normal".

Com problemas de enquadramento, imagem fora de foco, câmera sacudindo e falhas como riscos no negativo, tais cenas realmente parecem verdadeiras, como se fossem a versão não-editada de um documentário. O registro cinematográfico mostra que foram as "vítimas" que atacaram as tribos, na busca por imagens fortes e sensacionalistas, provocando a vingança dos índios, ironicamente registrada pelas suas câmeras.

O "documentário" termina com o fim do último dos jovens, Alan, que cai ensanguentado ao lado da própria câmera; o equipamento permanece ligado, registrando a morte do cinegrafista, numa cena que remete a flagrantes da vida real, como o episódio em que repórteres e políticos norte-americanos foram mortos pelos fanáticos de Jim Jones nos anos 70(2).
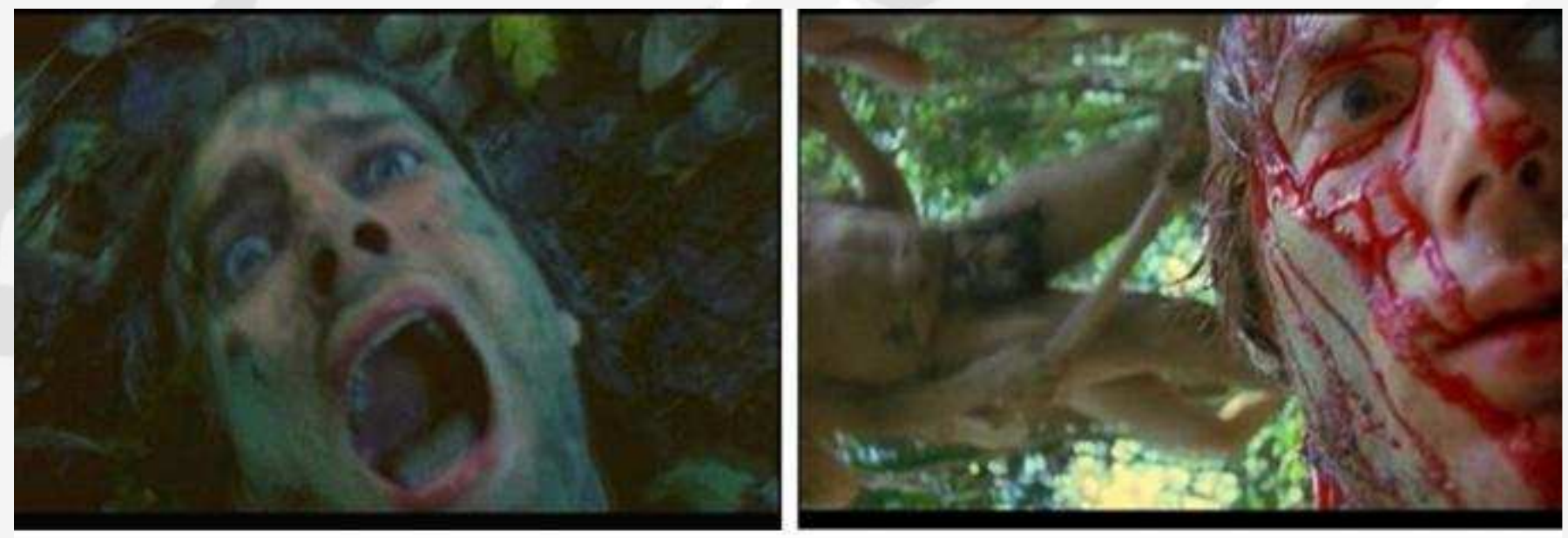

A câmera permanece filmando mesmo depois da morte de seus protagonistas.

Este jogo entre realidade e ficção e a forma como Canibal Holocausto sustenta até o fim o suposto "realismo" das suas imagens lembram algumas das principais teorias de Sergei Eisenstein e André Bazin.

Nunca lançado comercialmente no Brasil em VHS ou DVD (embora tenha sido exibido em algumas salas de cinema brasileiras na década de 80), Canibal Holocausto volta a chamar a atenção neste final de 2009: primeiro porque uma distribuidora finalmente anunciou o aguardado lançamento do filme em DVD no país; e segundo porque uma produção recente feita nos moldes da obra de Deodato, Atividade Paranormal (Paranormal Activity), dirigida por Oren Peli, revelou-se um grande sucesso de bilheteria(3)

Este artigo pretende discutir as ideias dos dois teóricos através da análise de cenas do filme. Eisenstein e Bazin foram escolhidos não necessariamente por serem "líderes" de correntes distintas (a montagem soviética e o neorrealismo), mas por suas teorias do cinema que atribuem à montagem, principalmente, um lugar central, ainda que em sentidos opostos: 
O que interessa a Bazin é quase exclusivamente a reprodução fiel, "objetiva" de uma realidade que carrega todo o sentido em si mesma, enquanto Eisenstein só concebe o filme como discurso articulado, assertivo, que só faz se sustentar por uma referência figurativa ao real. (AUMONT, 1995, p. 86)

Como estes dois teóricos reagiriam a uma sessão do filme de Deodato?

\section{Eisenstein e a montagem}

Nos primórdios do cinema, nas primeiras décadas do século 20, os russos estudaram com grande interesse o poder atrativo do cinema. E foi um cineasta da extinta União Soviética, chamado Lev Kuleshov, o primeiro a estabelecer "um dos conceitos mais consagrados da teoria cinematográfica: o específico do cinema é a montagem”. (XAVIER, 1983, p. 20)

Enquanto outros movimentos cinematográficos optavam por uma linguagem transparente, a escola soviética resolveu fundamentar seu trabalho sobre a seleção e a montagem, valorizando a montagem não como a reconstrução de um real imediato, mas sim como a construção de uma nova realidade - uma realidade cinematográfica.

Mas quem acabou desenvolvendo estas teorias da montagem de seus "camaradas" foi Sergei Eisenstein. Seus ideais, segundo Jean-Claude Bernardet: "de duas imagens, sempre nasce uma terceira significação"; e "a montagem não reproduz o real, ela é criadora; não reproduz, produz" (BERNARDET, 1980, p. 49).

Em suas teorias, reunidas nos livros $O$ Sentido do Filme (publicado originalmente em 1947) e A Forma do Filme (publicado originalmente em 1949), o cineasta russo defendia que o cinema não deveria se limitar a contar estórias quando podia produzir ideias.

O que incomodava Eisenstein nos filmes que via era a ineficiência. $\mathrm{O}$ cineasta, achava ele, estava à mercê dos acontecimentos que filmava, mesmo quando interpretados. A plateia olhava para os eventos cinematográficos exatamente como olhava para os acontecimentos cotidianos, tornando o cineasta mero canal através do qual a realidade podia ser reproduzida. (ANDREW, 1989, p. 55)

Desde seus primeiros filmes, Eisenstein mostrou-se inclinado a "provocar" o espectador, fazendo com que criasse associações e buscasse sentidos no que via na tela. Um exemplo disso é seu filme A Greve (1925)(4), em que, entre outras "colisões de planos", como escreveu Andrew, o cineasta justapôs o rosto de um homem com o de uma coruja, e editou paralelamente as imagens da repressão à manifestação de trabalhadores com outras do abate de um touro no matadouro. Segundo Andrew:

Enquanto D.W. Griffith e Pudovkin pretendiam levar o espectador a seguir em frente num transe em direção a uma conclusão que repentinamente explodiria à sua frente, vinda do nada, Eisenstein sempre insistiu na ajuda do espectador ao se forjar o significado do filme. (...) Essas imagens, cada uma proporcionando um forte estímulo, permanecem sem significado até que a mente cria as ligações entre elas através de sua capacidade metafórica. (...) Antes do final do filme o espectador consegue sintetizar suas ideias controladoras, ideias sobre capital versus trabalho. $\mathrm{O}$ filme atinge seu objetivo quando o espectador imagina a conclusão (ou síntese) da colisão de tais ideias principais. A síntese, nesse caso, é uma que demanda a derrubada do capitalismo e a ascensão da classe trabalhadora. (ANDREW, 1989, p. 71-72) 

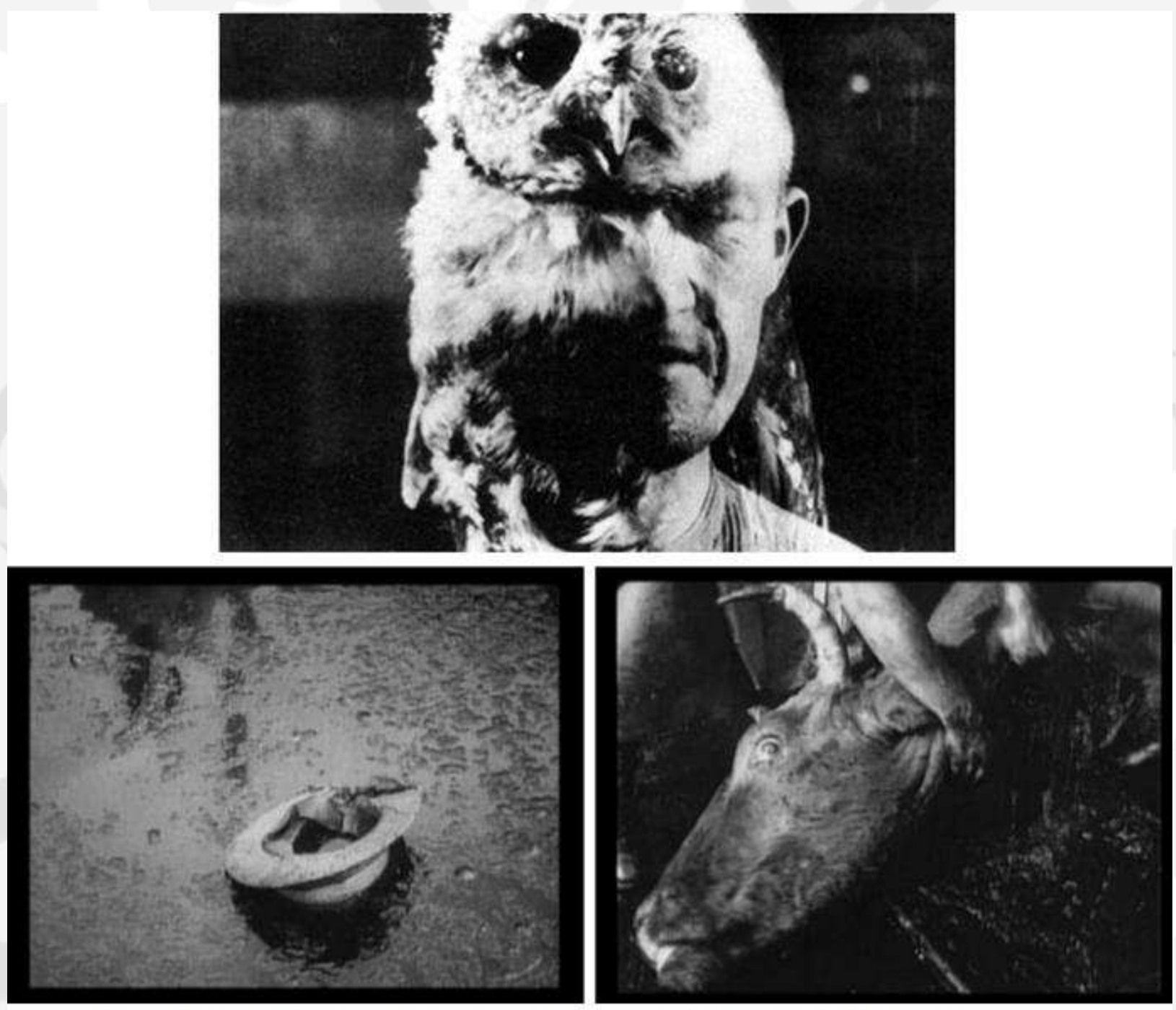

Alguns jogos de justaposição e montagem em "A Greve", de Eisenstein.

Eisenstein não via o filme como um produto, mas sim como um processo criativo do qual o próprio espectador participava, tanto emocional quanto intelectualmente. "Ao selecionar o material de montagem a ser fundido nesta ou naquela imagem particular que deve ser manifestada, devemos estudar a nós mesmos", escreveu ele em seu $O$ Sentido do Filme (2002, p. 52).

Para Andrew, o que Eisenstein defendia, ao contrário de outros diretores da época, não era a captura da realidade, mas sim a destruição do realismo, "decompor a aparência de um fenômeno e reconstruí-lo de acordo com um princípio da realidade" (ANDREW, 1989, p. 75). Eisenstein, conforme Andrew,

Surpreendia-se com a ineficiência e estupidez da maioria dos filmes, especialmente dos que procuravam dar à plateia a impressão de realidade. A realidade, achava, só fala de modo muito obscuro, quando fala. Depende do cineasta destruir a realidade e reconstruí-la, transformando-a num sistema capaz de gerar os mais profundos efeitos emocionais. O próprio senso de montagem de choque confirma isso. (Idem, p. 78)

À medida que o cinema evoluía tecnicamente, com o surgimento do som e da cor, Eisenstein adaptou as suas teorias para os novos formatos. Foi só surgirem os filmes falados, por exemplo, para que ele e os colegas cineastas Pudovkin e Grigori Alexandrov escrevessem a famosa Declaração Sobre o Som, que 
orienta:

Haverá exploração comercial da mercadoria mais vendável, os FILMES FALADOS. Aqueles nos quais a gravação do som ocorrerá num nível naturalista, correspondendo exatamente ao movimento na tela, e proporcionando uma certa "ilusão" de pessoas que falam, de objetos sonoros, etc. (...) Usar o som desse modo destruirá a cultura da montagem, porque cada ADESÃO do som a uma peça de montagem visual aumenta sua inércia como uma peça de montagem, e aumenta a independência de seu significado. (...) APENAS UM USO POLIFÔNICO do som com relação à peça de montagem visual proporcionará uma nova potencialidade no desenvolvimento e aperfeiçoamento da montagem. (EISENSTEIN, PUDOVKIN e ALEXANDROV apud EISENSTEIN, 2002, p. 225-226)

Dessa forma, Eisenstein tentava integrar uma invenção "realista" às suas teorias antirrealistas, defendendo a criação e o uso do que ele chamava de "contraponto orquestrado" entre imagem e som: uma forma de a trilha sonora e os efeitos sonoros integrarem diálogo e informação, porém em contraste com a imagem.

O que acrescenta ouvir ruídos de passos sobre uma imagem que mostra um homem andando? Nada. Mas se, ao contrário, o som não for o prolongamento da imagem, se houver um contraste entre os dois, então nascerá uma nova significação. (BERNARDET, 1980, p. 52)

\section{Bazin e a "realidade"}

Ao contrário de Eisenstein e outros teóricos do cinema, que reuniram seus ensaios e escritos em livros, o francês André Bazin nunca deixou uma obra sistemática com suas próprias teorias, que acabaram espalhadas em meio a críticas de filmes que ele escreveu para a revista Cahiers du Cinéma(5).

E embora ele tenha começado a coletar seus ensaios em 1957, sua morte no ano seguinte(6) interrompeu o desejo de publicar uma obra completa. Isso só foi feito postumamente, numa coletânea de quatro volumes chamada Qu'est-ce que le Cinéma? (O que é Cinema?), que reúne 60 dos seus ensaios(7) .

Os textos de Bazin são considerados os mais importantes da teoria realista do cinema, "exatamente como os de Eisenstein são os mais importantes das teorias formativas”, escreveu Andrew (1989, p. 138). Até porque os teóricos que defendiam essa tradição formativa não tiveram oposição até o fim da Segunda Guerra Mundial, quando as primeiras teorias sobre cinema realista de Bazin encontraram eco no surgimento do neorrealismo italiano.

Enquanto Marcel L'Herbier, Dziga Vertov(9) e a Escola Grierson(10) de diretores de documentários britânicos foram influentes defensores das propriedades "fotográficas" do cinema, André Bazin foi o primeiro crítico a efetivamente desafiar a tradição formativa. Foi sem dúvida a voz mais importante e inteligente a defender uma teoria e uma tradição cinematográficas baseadas na crença no poder das imagens mecanicamente registradas, e não no poder aprendido do controle artístico sobre tais imagens. (ANDREW, 1989, p. 138)

O francês concluiu que a matéria-prima do cinema não é a própria realidade, mas "o desenho deixado pela realidade no celuloide", conforme Andrew, que completa: "a arte cinematográfica é o que os diretores fazem com esses desenhos da realidade" (ANDREW, 1989, p. 146).

Tanto Malraux(11) quanto Eisenstein atribuem à montagem a plena capacidade artística do cinema, pois ela confere às imagens um desenho puramente mental, do mesmo modo que o ritmo confere aos sons um desenho que distinguimos como música. (...) Bazin foi o primeiro a ver que, 
por causa de suas origens naturais, o modelo sem adornos da realidade tem sua própria validade estética, se por isso entendemos uma descrição do existente de modo a focalizar a atenção sobre ele como se tivesse valor intrínseco. (Idem, p. 149)

Outro elemento que distingue Bazin dos demais teóricos de cinema da sua época é a crença nas possibilidades da "imagem sem adornos" e "da cena não-montada". Em outras palavras, na busca de um cinema mais realista, menos ancorado na teoria formativa, que conferia à montagem plenos poderes.

Teóricos e cineastas como Pudovkin e o próprio Eisenstein costumavam dizer que o cinema sem montagem não era uma arte. Pois Bazin propôs um contraponto à montagem:

[Era] a chamada técnica da "profundidade de campo", que permite a uma ação desenvolver-se durante longo período de tempo e em vários planos espaciais. Como o foco permanece nítido desde as lentes da câmera até o infinito, o diretor tem a opção de construir inter-relações dramáticas dentro do enquadramento (isso é chamado de mise em scène), em vez de entre os enquadramentos. Bazin prefere tal filmagem de profundidade de campo às construções de montagem por três razões: é inerentemente mais realista, alguns eventos demandam esse tratamento mais realista, e confronta nosso modo psicológico normal de processar eventos, chocando-nos dessa forma com uma realidade que frequentemente não conseguimos reconhecer. (ANDREW, 1989, p. 159)

Os ensaios do crítico francês encontraram eco no movimento chamado neorrealismo Italiano, que surgia na Itália do pós-guerra. Um de seus marcos iniciais é Roma, Cidade Aberta (Roma, Città Aperta, 1945), de Roberto Rossellini, filmado logo após a libertação de Roma com o fim da Segunda Guerra Mundial.

As produções neorrealistas têm diversos elementos em comum, como o grande uso de filmagens em externas ou em cenários naturais (ao invés de em estúdio, como era comum); o uso de atores nãoprofissionais; e, principalmente, a realização de filmes produzidos com menos recursos, distantes daquela estética de superprodução que caracterizou os grandes épicos italianos de antes da guerra.

Por causa disso, os filmes neorrealistas tinham um ar quase documental, que se encaixava no que Bazin vinha propondo, transformando-o num dos grandes entusiastas do movimento.

$\mathrm{Na}$ verdade, o teórico nunca condenou abertamente a montagem; apenas diminuía a sua importância, ao contrário do que rezava, antes, a tradição formativa. No livro que escreveu sobre Orson Welles(12), de quem era fã confesso, Bazin justificou: "A montagem clássica suprime totalmente esse tipo de liberdade recíproca entre nós e o objeto. Substituiu a livre organização por uma ruptura forçada, onde a lógica dos planos controlados pelo relato da ação anestesia completamente nossa liberdade" (BAZIN apud ANDREW, 1989, p. 164).

Não por acaso, ele considerava Cidadão Kane (Citizen Kane, 1941), o trabalho mais famoso de Welles, como um exemplo de suas teorias, devido ao grande uso de planos gerais e foco em profundidade para criar um clima de mistério e ambiguidade. E se não condenava especificamente a montagem, o francês era contrário ao abuso dela. Tanto que um de seus ensaios mais famosos chama-se justamente Montagem Proibida(13). Este ensaio começa com a crítica a dois filmes infantis franceses dirigidos por Albert Lamorisse(14), mas logo o autor começa a teorizar sobre o que chama de "montagem proibida", com um princípio básico:

Quando o essencial de um acontecimento depende de uma presença simultânea de dois ou mais fatores da ação, a montagem fica proibida. Ela retoma seus direitos a cada vez que o sentido da 
ação não depende mais da contiguidade física, mesmo se ela é implicada. (BAZIN, 1991, p. 62)

Por exemplo, Bazin não concordava que a cena da caçada a um tigre fosse mostrada através da montagem entre várias cenas, estilo plano/contraplano; para o teórico, os antagonistas deviam aparecer cara a cara no mesmo quadro, pois qualquer jogo de montagem seria "puro engodo".

E ele foi buscar no cinema mudo as justificativas para a "montagem proibida", citando tanto uma cena da comédia $O$ Circo (The Circus, 1928), em que Charles Chaplin aparece realmente dentro da jaula de um leão, sem trucagens ou edição, quanto o clássico momento em que o esquimó luta contra uma foca no documentário Nanook do Norte (Nanook of the North, 1923), de Robert Flaherty.

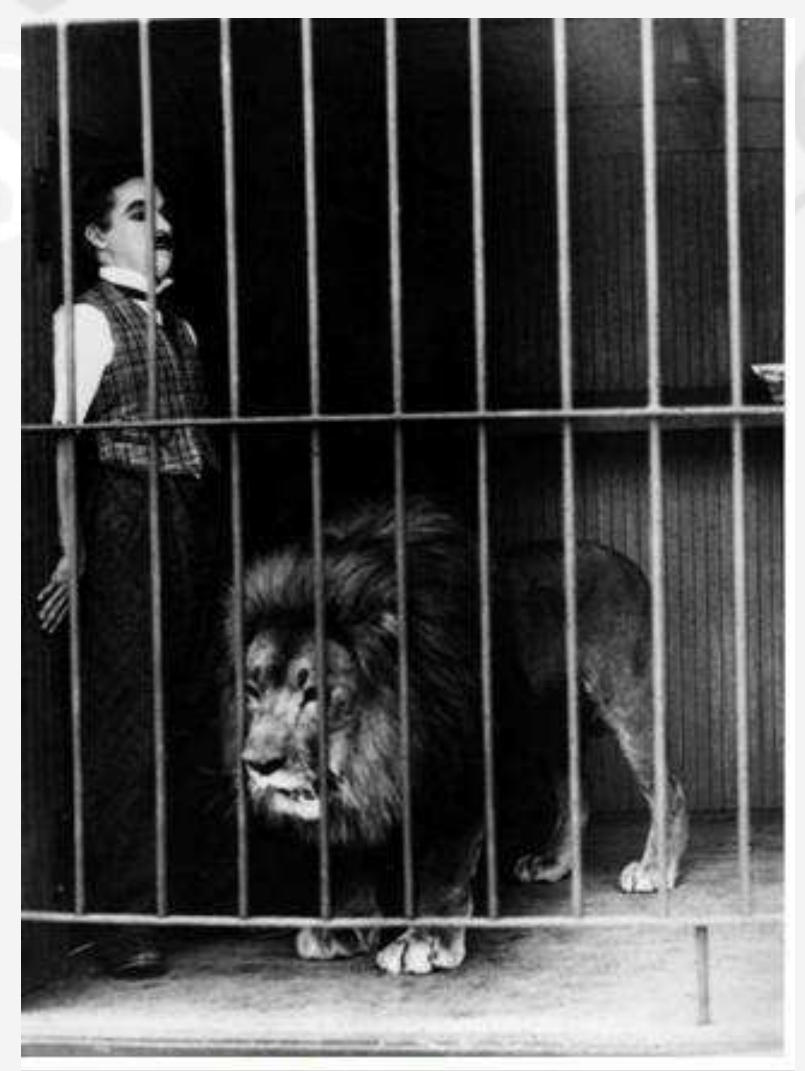

Chaplin na jaula do leão em "O Circo".

Bazin inclusive comparou esta cena de Nanook, filmada sem cortes, com um momento "editado" em outra obra dirigida por Flaherty, A História de Louisiana (Louisiana History, 1946):

Seria inconcebível que a famosa cena da caça à foca de Nanook, $O$ Esquimó não nos mostrasse, num mesmo plano, o caçador, o buraco e a foca. Pouco importa, porém, que o resto da sequência seja cortado à vontade pelo diretor. $\mathrm{O}$ que deve ser respeitado é a unidade espacial do acontecimento no momento em que sua ruptura transformaria a realidade em sua mera representação imaginária. (...) Se a imagem de Nanook espreitando sua caça na boca do buraco de gelo é uma das mais belas do cinema, a pesca do crocodilo, visivelmente realizada "na montagem" em Lousiana Story, é um desastre. Em compensação, no mesmo filme, o plano-sequência do crocodilo abocanhando a garça, filmado numa única panorâmica, é simplesmente admirável. Mas a recíproca é verdadeira: basta, para que o relato reencontre a realidade, que um único de seus planos convenientemente escolhidos reúna os elementos dispersados anteriormente pela montagem (BAZIN, 1991, p. 62). 
Aumont escreve que, ao contrário do que pregavam Eisenstein e outros teóricos russos, Bazin valorizava o "lucro de realismo" da filmagem em plano-sequência, argumentando que a montagem apenas reduzia "a ambigüidade do real, forçando-a a adquirir um sentido (forçando o filme a se tornar um discurso)", enquanto planos longos e profundos mostram "mais da realidade em um único e mesmo pedaço de filme" (AUMONT, 1995, p. 78).

E isso nos leva de volta a Ruggero Deodato e seu Canibal Holocausto.

\section{Eisenstein e Bazin em Canibal holocausto}

"Caro Ruggero, que filme! A segunda parte é uma obra-prima de realismo cinematográfico, mas tudo parece tão real que acho que você vai ter problemas no mundo inteiro" (LEONE apud SLATER, 2006, p. 108).

A frase acima faz parte de uma carta escrita pelo consagrado diretor italiano Sergio Leone ao seu conterrâneo Ruggero Deodato, após a estreia de Canibal Holocausto nos cinemas italianos, em 1980.

De certa forma, Leone estava prevendo os problemas que Deodato teria: devido à violência real contra animais e ao realismo das cenas de violência encenadas, Canibal Holocausto provocou polêmica e chegou a ser tirado de cartaz 10 dias após a estreia, enquanto seu diretor foi preso sob acusação de obscenidade e, posteriormente, homicídio.

As autoridades italianas acreditavam que Deodato realmente havia assassinado os atores diante da câmera, tal o realismo das cenas violentas. Ironicamente, esse era o objetivo do diretor, que inclusive pediu aos atores "mortos" que sumissem por uns tempos antes da estreia, mas depois foi obrigado a apresentar seus protagonistas no tribunal, provando que não estavam mortos(15) .

Mesmo assim, o filme permaneceu banido na Itália por três anos, e também provocou comoção e polêmica ao redor do mundo, sendo proibido em diversos países. No Brasil, Canibal Holocausto continuava inédito nas videolocadoras até novembro deste ano, quando a Platina Filmes anunciou seu lançamento em DVD.

Somente o tempo fez justiça ao trabalho de Deodato. Outrora uma "obscenidade", a obra passou a ser respeitada e estudada por autores e artistas influentes nos Estados Unidos e na Europa, transformando-se em filme de culto e ganhando status de clássico, além de ganhar inúmeras "edições de colecionador" em DVD em países como Estados Unidos, Itália, França e Alemanha.

Também deu origem a imitações famosas, como A Bruxa de Blair (The Blair Witch Project)(16), um sucesso independente lançado em 1999, dirigido por Daniel Myrick e Eduardo Sánchez, entre outros onde é adotado o mesmo estilo de "filmagem documental" anteriormente utilizado por Deodato.

Muitos fatores ligam Canibal Holocausto a Sergei Eisenstein e André Bazin. Primeiramente, a edição do filme (assinada por Vincenzo Tomassi) tem aspectos que remetem tanto às técnicas soviéticas de montagem (como as desenvolvidas por Eisenstein) quanto ao uso limitado da montagem, como incentivado por Bazin.

O diretor Deodato, na juventude, foi assistente de direção de Roberto Rossellini, e Canibal Holocausto traz certa herança do cinema neorrealista tão apreciado por Bazin. Além disso, o filme é considerado, talvez pretensiosamente, "o Cidadão Kane dos filmes de canibais", e Bazin era um grande entusiasta do 
clássico dirigido por Orson Welles.

O ponto principal que liga Eisenstein, Bazin e o filme de Deodato é a noção de "realidade". Antes de Canibal Holocausto, o diretor italiano já havia produzido outro filme sobre o tema, chamado Ultimo Mondo Cannibale, em 1977 (lançado em VHS no Brasil com o título O Último Mundo dos Canibais). Quase inteiramente rodado na selva (nas Filipinas), é um filme de ficção, mas que aproveitava sua ambientação e as cenas verídicas de animais sendo mortos para criar uma atmosfera de realismo e chocar o espectador, fazendo-o temer pela vida dos atores(17) .

Entre Ultimo Mondo Cannibale e Canibal Holocausto, outros diretores italianos fizeram filmes aproveitando o filão do canibalismo(18), mas sem o mesmo "refinamento" de Deodato; estas cópias não passavam de violentas aventuras na selva, embaladas com cenas grosseiras de violência e as tradicionais matanças reais de animais diversos.

Canibal Holocausto tem um quê de neorrealismo pelo fato de realmente ter sido filmado na Amazônia (em Letícia, na parte colombiana da floresta), com atores desconhecidos(19) e um clima de "filmeverdade" que produções feitas em estúdio não conseguem recriar.

Nesse aspecto, não importa se as tribos indígenas são "interpretadas" por figurantes que pouco ou nada lembram os verdadeiros índios amazônicos, pois os nomes de tribos verdadeiras foram utilizados no filme (yanomamo, shamatari), e a representação fica muito próxima da ideia que o público-alvo (principalmente o espectador europeu e norte-americano) tinha dos índios da América do Sul.

Além disso, nos créditos iniciais e finais do filme, há letreiros que tentam confundir ou enganar o espectador, levando-o acreditar que aquela é uma história real (não é) e que parte das cenas é verdadeira (também não é).

No começo, uma mensagem anuncia que "algumas cenas foram dramatizadas", e no final um letreiro explica que o projecionista que deveria destruir os rolos de filme gravados pelos documentaristas na verdade vendeu o material (seriam estas as cenas "reais" vistas em Canibal Holocausto).
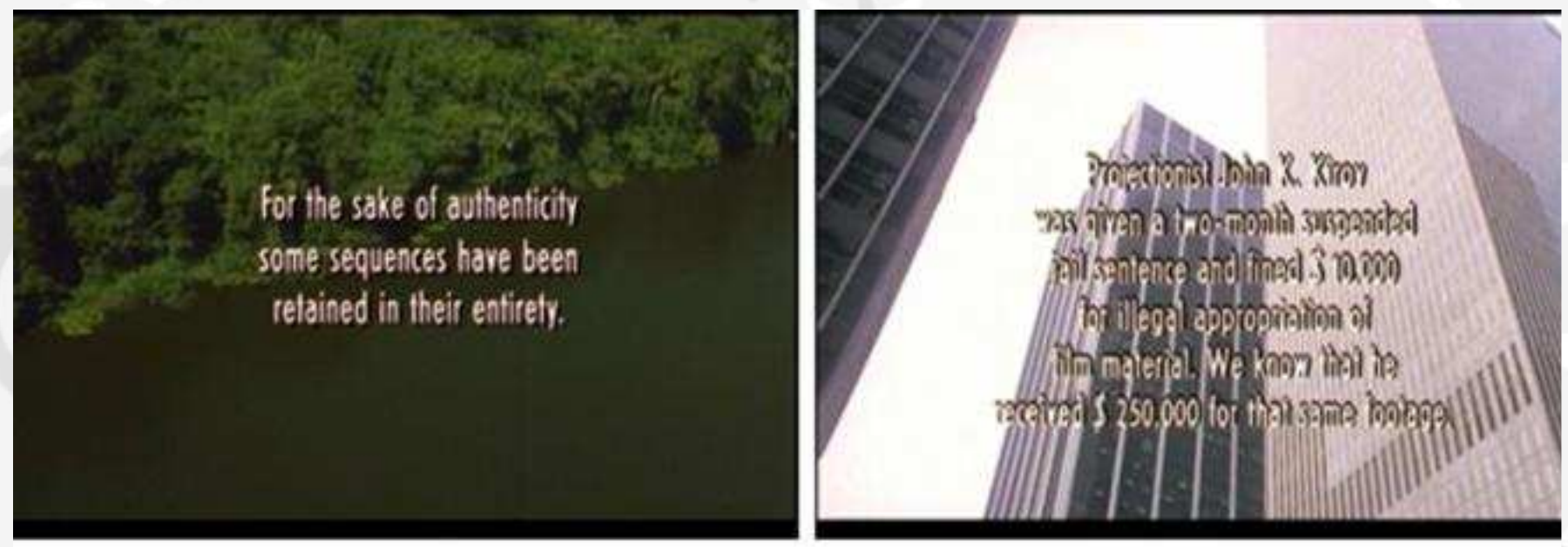

Letreiros no inicio e final do filme tentam atestar a "veracidade" da história.

Descontando óbvios exageros e liberdades poéticas dos seus realizadores, muitas cenas parecem reais em Canibal Holocausto, não só pelo filme ter sido rodado em plena selva, mas também por alguns criativos artifícios adotados por Deodato e sua equipe, como as supostas filmagens "verdadeiras" em $16 \mathrm{~mm}$, com 
todas as imperfeições que caracterizam gravações não-editadas.

Isso lembra o trecho de um dos ensaios de Bazin, citado por Andrew:

Bazin disse que amamos as fotografias cruas tiradas pelo montanhista Herzog(20) no topo do Everest porque "a câmera estava lá como o véu de Verônica colocado no rosto do sofrimento humano". Podem existir acuradas e belas fotografias de Cristo, mas nenhuma terá aquele etéreo senso de sua presença que o véu de Verônica afirma. De modo semelhante, Hollywood produziu em seus estúdios filmes excitantes e visualmente surpreendentes sobre escaladas de montanhas, mas nenhum tem a emoção autêntica das desajeitadas fotografias de Herzog tiradas nos momentos de crise real, pois esses momentos e essas crises foram preservados. (ANDREW, 1989, p. 144)

Dessa mesma maneira podemos olhar para Canibal Holocausto: existiram várias superproduções rodadas na própria Amazônia ou em recriações fiéis da selva, e mesmo alguns filmes italianos do período copiando os horrores antropofágicos de Deodato, mas poucos alcançam semelhante nível de realismo das cenas granuladas e "amadoras" de Canibal Holocausto.

E como o filme de Deodato trabalha com uma falsa realidade, também fica próximo dos ensaios do russo Eisenstein, que, ao contrário de Bazin e de outros teóricos, não aceitava "a noção do plano como um pedaço da realidade do qual o cineasta se apodera. Ele insistia de modo tão obstinado quanto lhe era possível em que o plano era o lócus de elementos formais como iluminação, linha, movimento e volume." (ANDREW, 1989, p. 59)

O fato de o próprio cinema tornar-se um personagem central de Canibal Holocausto - já que há a filmagem com câmera subjetiva, as cenas "reais" e a exibição de diversos procedimentos cinematográficos (filmagem, edição, projeção dos rolos de filme) - lembra outro cineasta russo, contemporâneo de Eisenstein: Dziga Vertov e seu Um Homem com uma Câmera.

Além disso, a Declaração Sobre o Som de Eisenstein, Pudovkin e Alexandrov encontra um belo exemplo tardio em Canibal Holocausto, já que cenas fortes de violência explícita (o esquartejamento da tartaruga, um estupro coletivo, uma aldeia de índios sendo queimada) aparecem embaladas pela belíssima música romântica composta por Riz Ortolani, que não combina nada com as imagens, e parece evocar a ideia de contraponto entre imagem e som defendida pelos soviéticos.

Finalmente, um outro aspecto em que o filme de Deodato lembra os ensaios de Eisenstein é a montagem, que vai acumulando cenas progressivamente mais fortes com a função de criar um contraste baseado em choques, ou atrações - o que o russo chamava de "cine-punho".

Andrew descreve, em As Principais Teorias do Cinema, a opinião de Eisenstein de que "um plano é uma simples etapa técnica da produção cinematográfica, um choque ou uma atração, por sua vez, é uma relação entre mente e tema; é uma questão de experiência da plateia e, em consequência um conceito muito mais sutil, muito mais rico" (ANDREW, 1989, p. 60).

Assim, na primeira parte do filme (a expedição em busca dos documentaristas desaparecidos), a montagem de Tomassi intercala cenas bastante mal-feitas - tiros que não furam corpos, aranhas visivelmente falsas - com as já mencionadas cenas reais de animais sendo mortos e esquartejados.

Mais tarde, quando outras cenas de violência falsas, mas convincentemente encenadas, são exibidas, já na parte final do filme, o espectador está condicionado a acreditar que os realizadores poderiam chegar àquele extremo; afinal, se animais verdadeiros foram mortos realmente nas cenas anteriores, por que 
aquelas pessoas, como a índia empalada, não poderiam estar sendo mesmo mortas?

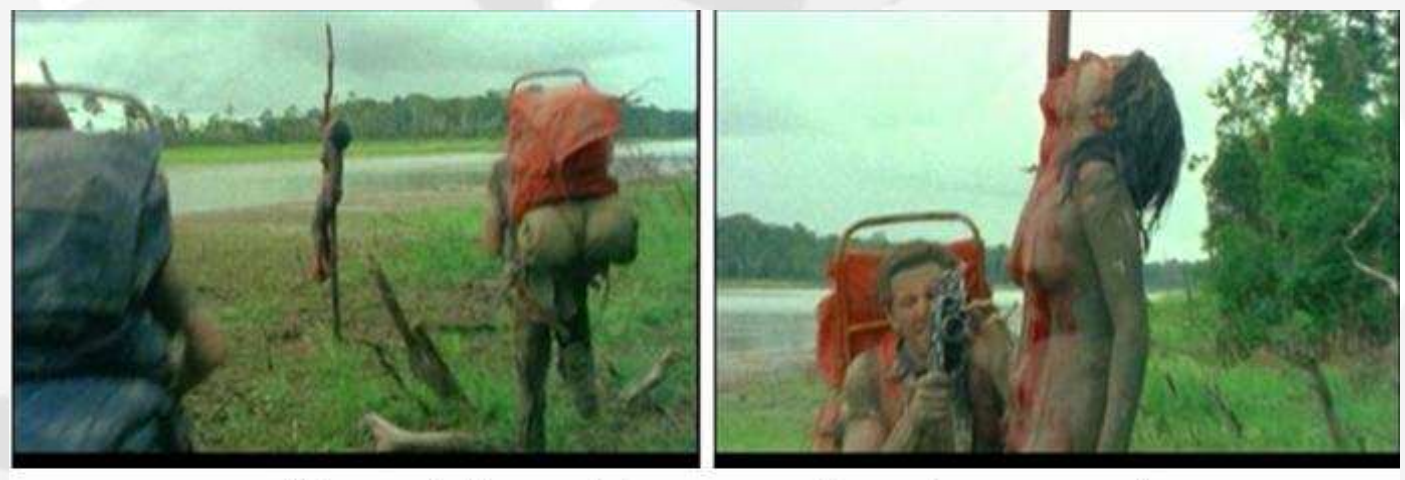

A famosa índia empalada: parece real, mas é apenas maquiagem.

Isso novamente lembra as teorias de Eisenstein, como explica Andrew:

Vimos que para ele [Eisenstein] a matéria-prima do cinema é a "atração", e que um filme é uma série de choques dados no espectador, uma espécie de máquina psicológica. A partir daí, a forma de um filme depende do tipo da experiência que o cineasta deseja evocar. O processo criativo, na realidade, começa com o artista conscientizando-se inteiramente do fim que tem em mente, decidindo então qual o melhor modo possível de atingir esse fim. (ANDREW, 1989, p. 70)

Em Canibal Holocausto, a montagem definitivamente faz parte do espetáculo, pois é ela que cria a ilusão de realidade em diferentes momentos. Uma cena em especial pode ser citada como um belo exemplo do experimento de "geografia criativa" de Kuleshov e da teoria da "montagem proibida" de Bazin, na tentativa de criar "suspense real". Trata-se da cena da jangada, que pode ser visualizada nas fotografias abaixo.
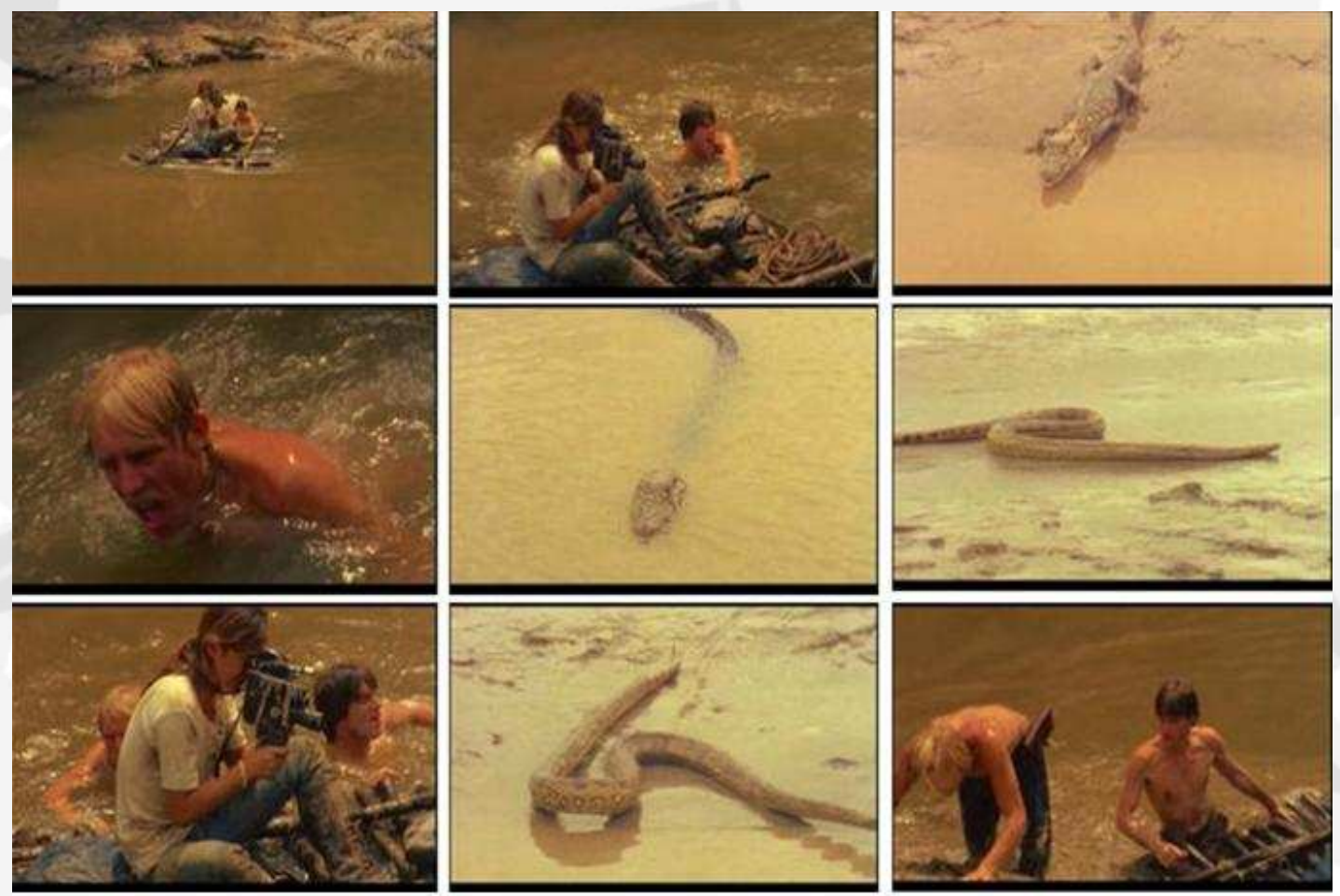

Cena da jangada ilustra o que Bazin chamava de "montagem proibida". 
Nesta cena, três dos documentaristas, Alan, Jack e Faye, atravessam o rio numa jangada improvisada, enquanto o quarto jovem, Mark, filma as imagens a que assistimos através de sua câmera; outros ângulos da mesma cena são vistos pela lente da segunda câmera, que Faye carrega sobre a jangada. Subitamente, um jacaré entra ameaçadoramente no rio e parece se aproximar dos jovens, que começam a nadar desesperados. Para a sorte deles, uma anaconda também entra no rio e assusta o jacaré, permitindo que eles cheguem seguros à margem.

Analisando as fotografias dos planos separadamente, fica bastante óbvio o que Bazin queria dizer com "montagem proibida": os três jovens na água, o jacaré e a anaconda não fazem parte da mesma cena e não estavam no mesmo rio no mesmo momento; as cenas com o jacaré e com a cobra podem até ter sido filmadas em outro local e outra época.

Mas a costura convincente destes planos através da montagem cria a falsa impressão de que os jovens realmente estão em perigo - impressão reforçada pelo uso da "câmera amadora" que sacode o tempo inteiro, uma trucagem relativamente simples.

Por outro lado, em vários momentos de Canibal Holocausto a câmera não pára de filmar, apresentando cenas num único take que respeitam o que Bazin defendia ao incentivar os longos planos sem cortes em oposição à "montagem proibida". É o caso das cenas com os animais sendo mortos diante da câmera, onde não há montagem nem trucagens, e sem a câmera desviar do alvo, registrando didaticamente os detalhes mais gráficos do abate.

E as cenas na parte final do filme, aquelas supostamente verdadeiras registradas pelas câmeras dos documentaristas mortos, também impressionam pela ausência de cortes ou montagem, tornando-as ainda mais realistas.

Uma delas é a morte de Jack: a câmera se aproxima num zoom para mostrar um dos canibais castrando o rapaz aprisionado; um jato de sangue sai do membro decepado, enquanto a câmera enquadra o rosto deformado da vítima após receber um golpe de tacape - tudo isso sem cortes e num único plano, como se aquela fosse a filmagem de um assassinato que estava realmente acontecendo.

As "colisões de planos", que Eisenstein tão bem utilizou em seus filmes para criar um sentido e um discurso, também podem ser encontradas em Canibal Holocausto, já que a ideia do diretor Deodato é criar o contraste entre "selvagens" e "civilizados", mostrando que uma linha bem tênue os separa.

É por isso que a primeira parte do filme mostra hábitos e rituais dos índios que podem ser considerados bárbaros pelo espectador, somente para que depois, na segunda parte, os "civilizados" documentaristas repitam as mesmas práticas do seu jeito.

Logo no início, é mostrado um ritual sexual violento entre um casal de nativos, quando a mulher é penetrada com um instrumento fálico feito de madeira, enquanto eles rolam pela lama. Mais adiante, os "civilizados" documentaristas se envolvem em uma situação tão "selvagem" quanto àquela, ao estuprarem uma nativa em meio à lama, evocando a cena inicial. 

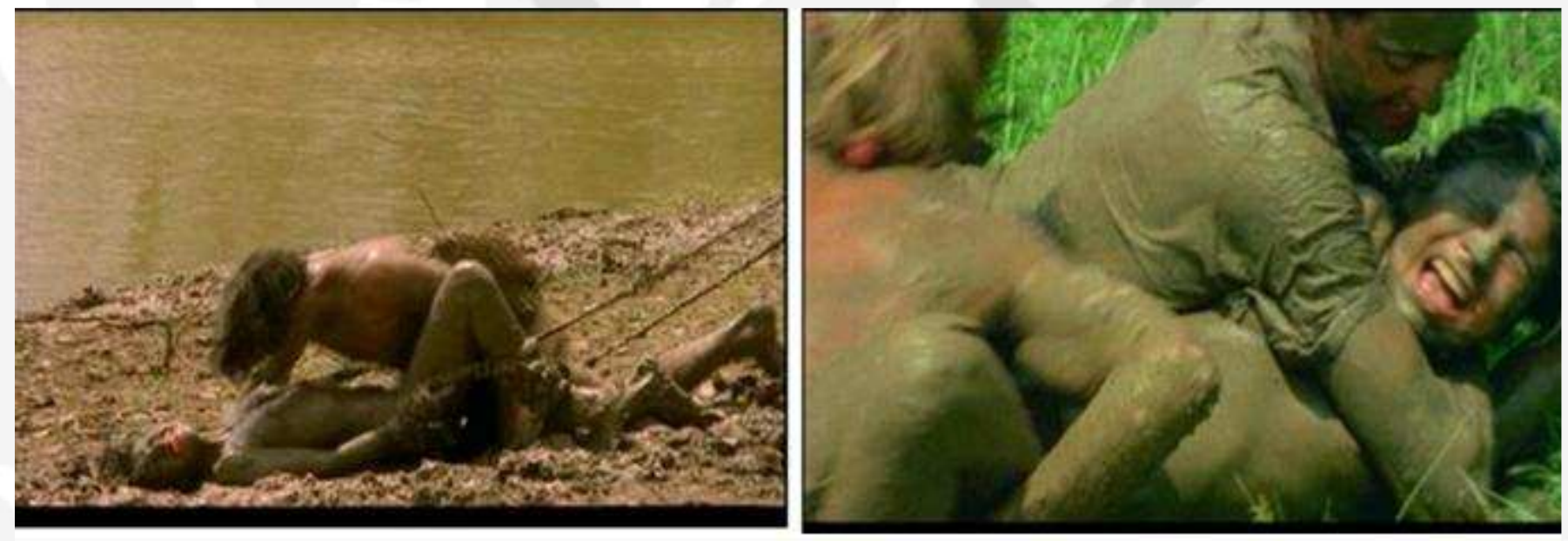

Estupros na lama: primeiro os "selvagens"; depois, os "civilizados".

Posteriormente, Alan e Faye fazem sexo de maneira quase selvagem numa aldeia que invadiram, sendo observados pelos índios ao longe. Quando, no final, a aprisionada Faye é estuprada, de forma "selvagem", por diversos canibais, o filme novamente remete à cena anterior.
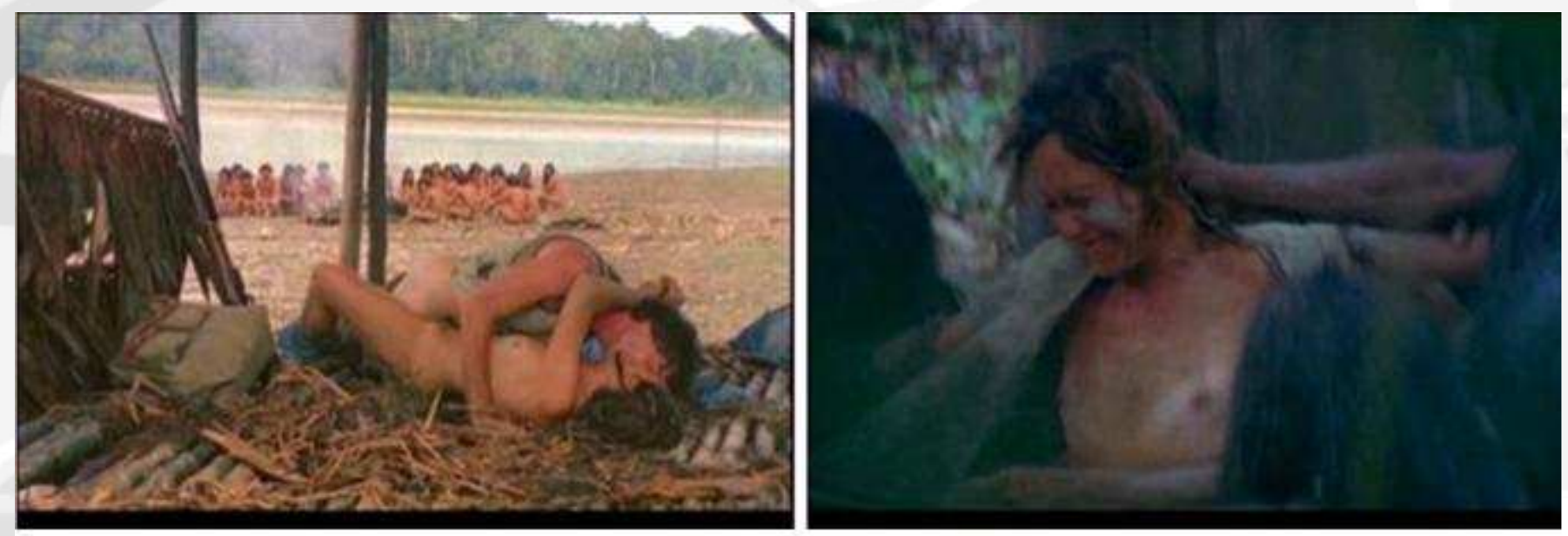

Sexo selvagem entre "civilizados" e sexo selvagem com os "selvagens".

Esta, por sinal, é a pergunta que o protagonista de Canibal Holocausto, o dr. Monroe, faz na conclusão do filme. Momentos antes, ele viu, com os empresários de uma poderosa rede de TV, as filmagens realizadas pelos quatro jovens mortos. Ironicamente, os executivos chegaram a cogitar a exibição de parte do material, eliminando as cenas mais "delicadas".

Isso leva Monroe a se questionar: "Quem são os verdadeiros canibais?". Nesse momento, novamente assinalando o contraste entre o mundo civilizado e o mundo selvagem, um caminhão passa na rua, exibindo um símbolo muito semelhante ao da tatuagem que um dos índios tinha na nuca em outra cena do filme - uma associação que nem é percebida pela maioria dos espectadores, mas está lá para sublinhar o 
discurso de Deodato.
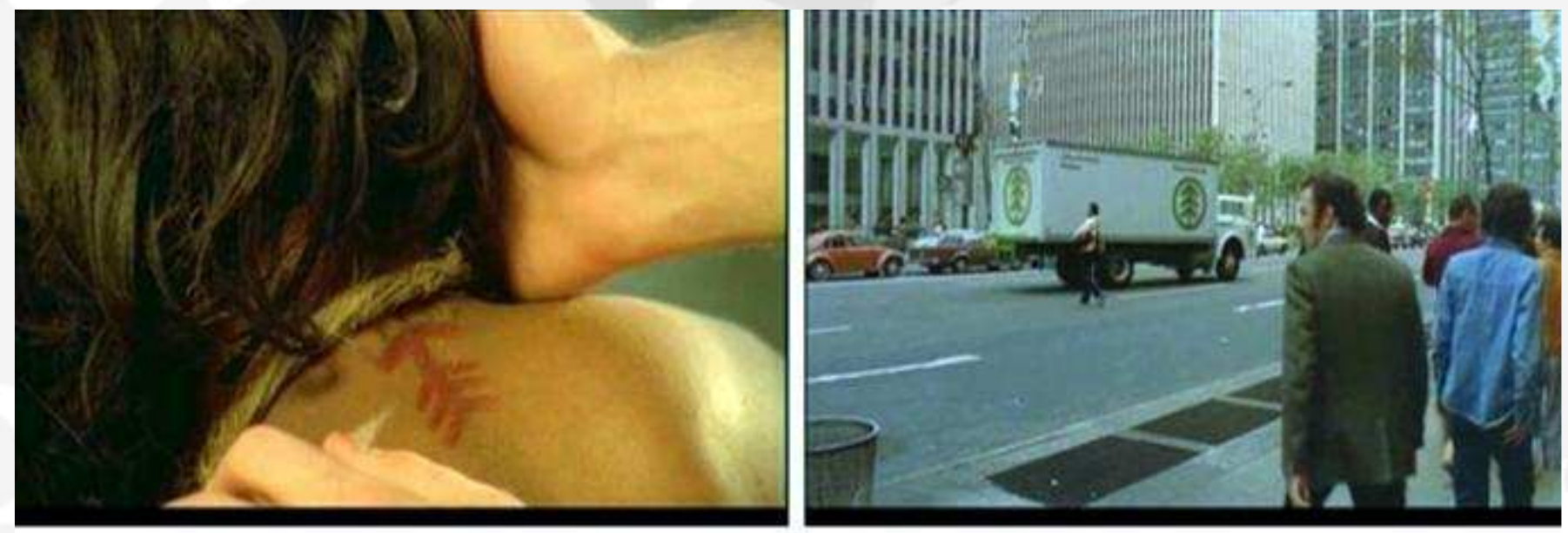

O simbolo visto na floresta, entre os "selvagens", também está na selva de pedra.

Trata-se do típico discurso eisensteniano do "cine-punho": contar a história através de imagens fortes, utilizando o choque entre elas para provocar o espectador. Neste caso, não é um discurso marxista, nem de operários contra patrões exploradores, mas a revolta dos colonizados (os índios que o espectador julga agressores selvagens no início, até descobrir que eles são as verdadeiras vítimas) contra os colonizadores (os "pobres" documentaristas que abusaram dos índios, e por isso foram mortos).

\section{Conclusão}

Recebido com polêmica na época do seu lançamento, e considerado maldito por muitos anos, Canibal Holocausto é um filme à frente do seu tempo, hoje até mais atual do que quando foi realizado - até pela quantidade de obras recentes que exploram a mesma técnica de "falso documentário", normalmente gerando grandes bilheterias nos cinemas e amplos debates e análises fora deles.

Embora normalmente associada ao sensacionalismo da sua proposta e à extrema violência das suas imagens, a obra de Ruggero Deodato permite várias leituras.

Percebe-se claramente que, ao contrário de outros cineastas italianos que fizeram filmes sobre canibalismo, como Umberto Lenzi ou Sergio Martino, Deodato não só teve um melhor domínio da técnica e da narrativa, como também se mostrou mais articulado para realizar uma obra ao mesmo tempo chocante e inteligente, que assusta e faz pensar.

E isso não só pelo fato de Canibal Holocausto evocar, como vimos, teorias do cinema tão opostas quanto aquelas escritas por Sergei Eisenstein e André Bazin na primeira metade do século passado, mas principalmente pelo atualíssimo debate da violência na mídia e do sensacionalismo da comunicação.

$\mathrm{Na}$ época em que Canibal Holocausto foi produzido, no final dos anos 70, o diretor Deodato e muitas pessoas no mundo inteiro ainda tinham vívidas as memórias de chocantes imagens verídicas apresentadas pela televisão, como o presidente John F. Kennedy sendo alvejado na cabeça ou as execuções sangrentas durante a Guerra do Vietnã. Hoje, 30 anos depois, a situação não mudou muito: os mortos em conflitos no Iraque ou na Faixa de Gaza são mostrados em detalhes sangrentos no horário nobre, e com um único clique é possível assistir aos vídeos "sem cortes" das decapitações de reféns por terroristas no Afeganistão, via internet. 
Para piorar, fatos recentes envolvendo tanto a comunicação quanto o entretenimento televisivo parecem sinalizar que, como Deodato mostrou, as imagens podem ser manipuladas para iludir o espectador, seja através da já antológica entrevista falsa com supostos membros do PCC (exibida por Gugu Liberato em seu programa Domingo Legal há alguns anos), seja através da suposta "realidade" dos ironicamente chamados reality shows, como o Big Brother Brasil, onde os participantes visivelmente interpretam papéis para tentar sensibilizar o público e garantir sua permanência no programa - ou pelo menos aumentar a audiência.

Por permitir discussões como essa é que Canibal Holocausto continua tão sedutor e polêmico. Como vários clássicos do horror, o filme de Ruggero Deodato permanece não só como um retrato do tempo em que foi realizado, mas também como uma obra de referência, que continua atual.

\section{Bibliografia:}

ANDREW, J. Dudley. As principais teorias do cinema. Rio de Janeiro: Jorge Zahar, 1989. 274 p.

AUMONT, Jacques. A estética do filme. Campinas, SP: Papirus, 1995. 314 p.

BAZIN, André. O cinema - Ensaios. São Paulo: Brasiliense, 1991. 341 p.

BERNARDET, Jean-Claude. O que é cinema? São Paulo: Brasiliense, 1980. 118 p.

EISENSTEIN, Sergei. A forma do filme. Rio de Janeiro: Jorge Zahar, 2002. 236 p.

EISENSTEIN, Sergei. O sentido do filme. Rio de Janeiro: Jorge Zahar, 2002. 162 p.

Página de Cannibal Holocaust no Internet Movie Database. Disponível em http://www.imdb.com/title/tt0078935. Acesso em 19 de julho 2009.

SLATER, Jay. Eaten alive: Italian cannibal and zombie movies. New Jersey: Plexus, 2006. 256 p.

XAVIER, Ismail (org.). A experiência do cinema. Rio de Janeiro: Graal, 1983. 480 p.

\section{Notas:}

(1) Termo em inglês para documentários falsos, numa fusão das palavras mock (farsa) e documentary (documentário). Existem diversos exemplos famosos, como Isto é Spinal Tap (This is Spinal Tap 1984), "documentário" sobre uma falsa banda de rock, e Dark Side of the Moon (2002), que apresenta "evidências" de que a chegada do homem à Lua foi uma farsa encenada pelo cineasta Stanley Kubrick com apoio do governo norte-americano.

(2) Em novembro de 1978, o congressista norte-americano Leo Ryan liderou um grupo de políticos e jornalistas até Georgetown, na Guiana, para investigar informações de violação dos direitos humanos na comunidade religiosa administrada pelo reverendo Jim Jones (e chamada "Jonestown"). Durante a visita, Ryan foi atacado por um dos homens de Jones, mas a delegação conseguiu sair da comunidade levando 15 dos seus membros, que desejavam voltar aos Estados Unidos. Mais tarde, na hora do embarque no aeroporto de Georgetown, a comitiva foi atacada por homens armados a mando de Jim Jones, quando nove pessoas foram mortas a tiros. Uma delas foi Bob Brown, cinegrafista da NBC que filmou os 
primeiros segundos do ataque, e cuja câmera continuou filmando quando ele próprio foi assassinado. As cenas foram exibidas na TV na época, provocando grande comoção e também polêmica sobre a violência na mídia. Dias depois, Jim Jones lideraria o suicídio coletivo de sua comunidade, provocando a morte de mais de 900 pessoas.

(3) O filme, produzido em 2007 e lançado apenas em 2009 nos cinemas mundiais, custou 15 mil dólares e, até 29 de novembro de 2009, já havia arrecadado mais de US\$ 107 milhões de bilheteria apenas nos cinemas norte-americanos, segundo o site Internet Movie DataBase.

(4) A Greve (Stachka!) é o segundo filme de Eisenstein e conta a história da greve de operários de uma fábrica em 1912, motivada pelo suicídio de um deles, após falsa acusação de roubo movida pelos patrões. No final, a manifestação dos trabalhadores é brutalmente reprimida pelos militares.

(5) A revista Cahiers du Cinéma foi fundada em 1951 por Bazin, Jacques Doniol-Valcroze e JosephMarie Lo Duca, tornando-se uma das mais influentes e respeitadas publicações sobre cinema do mundo. Entre os autores da primeira fase da revista estavam futuros cineastas respeitados, como Jean-Luc Godard, Claude Chabrol e François Truffaut. A Cahiers é publicada até hoje.

(6) Em 11 de novembro de 1958, aos 50 anos de idade.

(7) No Brasil, diversos de seus textos foram publicados pela Editora Brasiliense no livro O Cinema Ensaios, publicado em 1991.

(8) L'Herbier foi um escritor francês, produtor e diretor de cinema, que dedicou-se aos estudos da estética e teoria da sétima arte. Um de seus filmes mais famosos mostra manchas de cores primárias, impressas na película, respondendo a sons variados.

(9) Vertov, cujo nome verdadeiro era Denis Abramovich Kaufman, foi um cineasta, documentarista e jornalista russo, grande precursor do que se convencionou chamar de "cinema verdade", através de filmes como Um Homem com uma Câmera (Chelovek S Kino-Apparatom, 1929).

(10) A Escola Grierson foi fundada pelo escocês John Grierson, que, ao lado de Robert Flaherty e Dziga Vertov, é considerado um dos principais nomes dos primórdios do documentário. Sua escola inglesa ajudou a lançar as bases para o chamado documentário clássico. Sua obra mais famosa é Drifters (1929).

(11) André Malraux foi um famoso teórico e pensador francês.

(12) Chamado Orson Welles, foi publicado originalmente em 1978, muitos anos após a morte de Bazin.

(13) Um texto originalmente publicado na Cahiers du Cinéma em 1953, e incluído na edição brasileira $O$ Cinema - Ensaios, da Editora Brasiliense.

(14) Bim, Le Petit Âne (1950) e Crin Blanc-Le Cheval Sauvage (1953).

(15) Alguns dos protagonistas, como Gabriel Yorke, Perry Pirkanen e Francesca Ciardi, não tiveram outros trabalhos de grande expressão nos anos seguintes, o que aumentou a boataria de que foram realmente assassinados.

(16) A Bruxa de Blair tem enredo muito semelhante ao de Canibal Holocausto, apresentando as supostas filmagens reais de três jovens cineastas que desapareceram enquanto faziam um documentário sobre "a 
bruxa de Blair" em uma floresta norte-americana. Na época em que o filme foi lançado, falsos sites na internet e até um mockumentary chamado A Maldição da Bruxa de Blair (Curse of the Blair Witch, 1999) tentavam vender a ideia de que tudo era real, e que os três jovens vistos no filme realmente tinham morrido, o que transformou A Bruxa de Blair num sucesso instantâneo (custou US\$ 60 mil e rendeu mais de US\$ 248 milhões nas bilheterias mundiais).

(17) O trailer original do filme mostrava a equipe preparando uma cena e o diretor Deodato comentando, diretamente para a câmera, que eles estavam filmando em meio à selva e cercados por canibais de verdade, e que um dos membros da equipe supostamente estaria desaparecido há dias, provavelmente devorado pelos índios.

(18) Entre eles, A Montanha dos Canibais (La Montagna del Dio Cannibale, 1978), de Sergio Martino, e Os Vivos Serão Devorados (Mangiati Vivi!, 1980), de Umberto Lenzi.

(19) O menos obscuro era Robert Kerman, intérprete do professor Monroe, que na época tinha uma carreira bem-sucedida como ator de filmes pornográficos. Sob o pseudônimo "Robert Bolla", Kerman apareceu em mais de 150 filmes adultos entre 1974 e 1986, segundo o Internet Movie DataBase, fazendo inclusive obras famosas como Taboo American Style e Debbie Does Dallas. Mais recentemente, apareceu em ponta no filme Homem-Aranha (Spiderman, 2002).

(20) Bazin refere-se ao alpinista francês Maurice Herzog, que em junho de 1950 escalou não o Everest, mas a montanha Annapurna, no Himalaia, tornando-se a primeira pessoa a escalar um monte com mais de 8.000 metros de altura. No trecho final da escalada, Herzog perdeu as luvas e ficou com os dedos das mãos congelados; para evitar gangrena, o médico da equipe teve que amputá-los sem anestesia. O Everest só seria "conquistado" em 1953, por Edmund Hillary e Tenzing Norgay. Como Herzog não escalou o Everest, trata-se de um engano de Bazin ao escrever seu artigo.

\section{Mini Currículo :}

Felipe M. Guerra é mestrando em Comunicação da Universidade Anhembi Morumbi, São Paulo, com bolsa da Coordenação de Aperfeiçoamento de Pessoal de Nível Superior (CAPES). Atualmente desenvolve a pesquisa $O$ diabo também é brasileiro - A figura do demônio no cinema nacional, orientada por Rogério Ferraraz. 